\title{
How does total laryngectomy affect taste and smell senses
}

\section{Total Larenjektominin Tat ve Koku Duyuları Üzerine Etkisi}

\author{
Tuncay Tunçcan, Elif Akyol Sen, Sema Zer Toros, Ayça Ant, Arzubetül Duran \\ ${ }^{1}$ Ankara Onkoloji Eğitim Ve Araştırma Hastanesi Kulak Burun Ve Boğaz Hastalıkları Kliniği Ankara, Türkiye \\ ${ }^{2}$ Haydarpaşa Numune Eğitim Ve Araştırma Hastanesi Kulak Burun Ve Boğaz Hastalıkları Kliniği Istanbul, \\ Türkiye
}

\section{ÖZET}

GíRIŞ ve AMAÇ: Total Larenjektominin tat ve koku duyuları üzerine olan etkisinin değerlendirilmesi YÖNTEM ve GEREÇLER: Tat ve Koku duyularının değerlendirilmesi amaçlı kullandığımız testler, kolay uygulanabilir ve noninvaziv testlerdir. Koku duyusunun değerlendirilmesi CCCRC koku identifikasyon ve nbutanol eşik testi ile üç farklı konsantrasyonda (düşük, orta, yüksek) uygulanarak değerlendirildi. Tat testi 4 ana solüsyon ( tatlı, acı, ekşi, tuzlu) ile değerlendirildi. Tat ve koku değerlendirme sonuçları istatiksel olarak analiz edildi.

BULGULAR: Total larenjektomili hastalarda koku testleri ile anosmi ve şiddetli hiposmi tespit edildi. Bu 10 bulgular bize total larenjektomide koku duyusu bozukluğu meydana geldiğini gösterdi. Tat testlerinde solüsyon yoğunluğu ve tada göre farklı sonuçlar görüldü, hastalar ekşi tadı tatlı, acı ve tuzludan daha iyi algıladı. TARTIŞMA ve SONUÇ: Total larenjektomi tat ve koku duyularında azalmaya neden olabildiği gözlemlenmiş̧ir.

Anahtar Kelimeler: Tatol larenjektomi, tat duyusu, koku duyusu

ABSTRACT
INTRODUCTION: Evaluation of taste and smell senses alteration in total laryngectomy MATERIAL and METHODS: The materials which were used for evaluation of taste and smell senses were easily provided and the tests were non-invasive. The smell sense was evaluated by using CCCRC smell identification test and n-butanol thresold test where taste sense was evaluated by using 3 different concentrations (low-medium-high) of four main taste (sweet, bitter, sour and salty) solutions. Results of taste and smell evaluation tests were statistically analized.

RESULTS: Anosmia and severe hyposmia were evaluated in smell sense tests of total laryngectomy received patients. This finding shows the disfunction of smell sense in total laryngectomy. Different results of taste sense tests were found according to the kind and concentration of solutions; patients sensed sour solutions better than sweet, bitter and salty solutions.

DISCUSSION AND CONCLUSION: Total laryngectomy can causes decrease in olfactory functions and taste functions

Keywords: Total laryngectomy, taste sense, smell sense

\section{INTRODUCTION}

Total laryngectomy was the preferred procedure for advanced stage larynx cancers for years. However, the indications of this procedure is limited in present and less preferred. The upper respiratory tract is out of order after laryngectomy. Nasal mucosa is disassociated to breathed air because of tracheostomy and there is failure in mucosiliar activity on mucosal surface of the nose. Taste, smell and swallow disfunctions occur after total laryngectomy $(1,2,3)$.

Smelling is sensed by trigeminal, glossopharengeal and vagal nerves however nervus olfactorius is the leading one. Nervus olfactorius is stimulated when molecules related to smelling reaches to olfactorial 
region. Although molecules reaches to the olfactorial region by diffusion as well, special air flow called ortonasal air flow has the main role. Half of physiological air flow passes by medial meatus where $35 \%$ of it passes by inferior meatus and $15 \%$ by olfactorial region $(4,5)$. Nasal mucosal status affects the function of nervus olfactorius as well. Optimum smelling is possible in presence of medium congestioned, moistured and red nasal mucosa. Nevertheless, it is known that physiological congestion-decongestion cycle (nasal cycle) of the mucosa does not affect efficiency of smelling (6).

As it is difficult to differentiate mix tastes, different concentrations of 4 main tastes are used in evaluation. The typical elements used in different concentrations are $\mathrm{NaCl}$ (Sodium Chloride), sucrose, citric acid and quinine hydrochloride or quinine sulphate. Solutions are prepared by using these elements in different concentrations in order to test the taste sense on patients. It seems to be a good technique to measure sensation thresold as the clinician needs to distinguish the minimum concentration of only one element (7)

Although it is known that physiology of the nasal mucosa changes when the nose looses its air way function after laryngectomy, there are not enough studies in literature about the changes in taste sense after this surgical procedure $(8,9)$. The purpose of the present study is to evaluate taste and smell sensations of total laryngectomy received patients.

\section{MATERIAL and METHODS}

The study protocol was approved by the Ethics Committee of Haydarpasa Numune Training and Research Hospital, Istanbul, Turkey. Twenty patients who were operated because of larynx cancer between the years 2002-2012 in Department of Ear-Nose-Throat and HeadNeck Surgery of Haydarpasa Numune Training and Research Hospital are evaluated. All the patients received total laryngectomy and bilateral lateral level 2,3,4 neck dissection. In order to evaluate smell and taste functions clearly, patients who have spent more than 1 year over total laryngectomy have been included in the study. Patients who had primary or metastatic tumours of oral base and oral cavity, anatomic disorders which caused nasal obstruction, allergic symptoms, central nervous system deficit and the ones who received surgery related to taste and smell before were excluded.

All the patients were male and none received adjuvant chemotherapy, or radiotherapy however there were There were no nasopharyngeal disorder at the endoscopic examination of the patients. All the patients gave up smoking before surgery.

History, physical and endoscopic examination as well as radiological imagings were used in recognizing the disorders which might affect taste and smell functions adversely and 20 patients were reached suitable for study.

Evaluation of smell sensation: First of all, smell sensation thresold is ascertained by using n-butanol, then CCCRC test was used to determine smell sensation.

N-Butanol was prepared in 7 different concentrations. $4 \%$ n-butanol was the most concentrated solution and next concentrations were prepared by adding distilled water by $1 / 3$ ratio into the one more concentrated solution. Patients began to smell the most diluted nbutanol solution at first and then the others respectively. The thresold concentration was the one that the patient distinguished it from water.

Seven different concentrations of $n$ butanol and vicks were used to perform CCCRC test. The ability to sense Vicks indicates intact trigeminal nerve function. Possible scores ranged from 0 to 7 items correctly identified. Scores for both nostrils were averaged to arrive at the final score. Scores for the butanol threshold test and identification tests were subsequently averaged to arrive at a composite score for orthonasal olfactory ability. According to CCCRC test, scores were grouped by category as $0-1.75$ score revealed anosmi; 2.00-3.75 score revealed severe hyposmia; 4.00-4.75 score revealed moderate hyposmia and 5.00-5.75 score revealed mild hyposmia. The score 6.007.00 showed normosmia.

Evaluation of taste sensation: Four different solutions were used in 3 different concentrations in order to determine taste 
sensation. For evaluation of taste sensation; Citric acid was used for determining sour taste and diluted by distilled water in $0.01,0.05$ ve $0.25 \mathrm{~g} / \mathrm{ml}$ concentrations; quinine hydrochloride was used to determine bitter taste and diluted by distilled water in 0.0001 , 0.0005 ve $0.0025 \mathrm{~g} / \mathrm{ml}$ concentrations; sucrose was used to determine sweet taste and diluted by distilled water in $0.01,0.05,0.25 \mathrm{~g} / \mathrm{ml}$ concentrations and sodium chloride was diluted by distilled water in $0.005,0.025$ ve $0.125 \mathrm{~g} / \mathrm{ml}$ concentrations to determine salty taste. Patients did not drink or eat anything except water at least one hour and cotton sticks imbued with every concentrated solution applied 3 seconds over the tongue.

All analyses were performed by using NCSS (Number Cruncher Statistical System) 2007\&PASS (Power Analysis and Sample Size) 2008 Statistical Software (Utah, USA). Descriptive statistics were used to calculate frequencies and percentages for all variables involved. Categorical values were determined using the Fisher's exact test and Yates Continuity Correction test. A $\mathrm{p}$ value less than 0.05 was considered as statistically significant.

\section{RESULTS}

Patients' age ranged between 48-80 years and the mean age was 61.25 years. All the patients were male. The thresold values ascertained by butanol ranged between $0-7$ and the mean value was $3,95 \pm 2,63$.

According to CCCRC test results there were 10 severe hyposmic patients and 10 anosmic patients. About matter and detection status on table I.

All the patients which CCCRC results revealed anosmia and severe hiposmia were unable to sense $0,0001 \mathrm{~g} / \mathrm{ml}$ concentrate of quinine hydrochloride solution. There was no statistically difference between severe hyposmic and anosmic patients in sensation of $0,0005 \mathrm{~g} / \mathrm{ml}$ and $0,0025 \mathrm{~g} / \mathrm{ml}$ concentrations of quinine hydrochloride solution ( $p>0,05)$.

All the patients which CCCRC results revealed anosmia and severe hiposmia were able to sense $0,25 \mathrm{~g} / \mathrm{ml}$ concentration of sucrose solution. The patients with severe hyposmia sensed $0,01 \mathrm{~g} / \mathrm{ml}$ concentration of sucrose solution better than the patients with anosmia, but this was not statistically significant $(p>0,05)$. There was no statistically significance between severe hyposmic and anosmic patients in sensation of $0,05 \mathrm{~g} / \mathrm{ml}$ concentration of sucrose solution. Both anosmic and severe hyposmic patients could not sense $0,005 \mathrm{~g} / \mathrm{ml}$ concentration of $\mathrm{NaCl}$ solution. There was no statistically difference between anosmic and hyposmic patients in sensation of both $0,025 \mathrm{~g} / \mathrm{ml}$ and $0,125 \mathrm{~g} / \mathrm{ml}$ concentration of $\mathrm{NaCl}$ solutions ( $p>0,05)$. All of the severe hyposmic patients sensed all the concentrations of citric acid solutions. All of the anosmic patients sensed $0,05 \mathrm{~g} / \mathrm{ml}$ and 0,25 $\mathrm{g} / \mathrm{ml}$ concentrations of citric acid solutions, however only $60 \%$ of them were able to sense $0,01 \mathrm{~g} / \mathrm{ml}$ concentration of citric acid solution and this finding was not statistically significant as well $(\mathrm{p}>0,05)$.

Table 1: Detection status of different matters.

\begin{tabular}{|c|c|c|c|}
\hline Matter & $\begin{array}{c}\text { Detection } \\
\text { Status }\end{array}$ & $\mathbf{N}$ & $\%$ \\
\hline \multicolumn{4}{|l|}{ Citric Asid } \\
\hline \multirow{2}{*}{$0.01 \mathrm{~g} / \mathrm{ml}$} & + & 16 & 80 \\
\hline & - & 4 & 20 \\
\hline $0.05 \mathrm{~g} / \mathrm{ml}$ & + & 20 & 100 \\
\hline $0.25 \mathrm{~g} / \mathrm{ml}$ & - & 20 & 100 \\
\hline \multicolumn{4}{|c|}{$\begin{array}{l}\text { Quinine } \\
\text { Hydrochloride }\end{array}$} \\
\hline $0.0001 \mathrm{~g} / \mathrm{ml}$ & - & 20 & 100 \\
\hline \multirow{2}{*}{$0.0005 \mathrm{~g} / \mathrm{ml}$} & + & 7 & 35 \\
\hline & - & 13 & 65 \\
\hline \multirow{2}{*}{$0.0025 \mathrm{~g} / \mathrm{ml}$} & + & 17 & 85 \\
\hline & - & 3 & 15 \\
\hline \multicolumn{4}{|l|}{ Sucrose } \\
\hline \multirow{2}{*}{$0.01 \mathrm{~g} / \mathrm{ml}$} & + & 3 & 15 \\
\hline & - & 17 & 85 \\
\hline \multirow{2}{*}{$0.05 \mathrm{~g} / \mathrm{ml}$} & + & 10 & 50 \\
\hline & - & 10 & 50 \\
\hline $0.25 \mathrm{~g} / \mathrm{ml}$ & + & 20 & 100 \\
\hline \multicolumn{4}{|l|}{$\mathrm{NaCl}$} \\
\hline $0.005 \mathrm{~g} / \mathrm{ml}$ & - & 20 & 100 \\
\hline \multirow{2}{*}{$0.025 \mathrm{~g} / \mathrm{ml}$} & + & 17 & 85 \\
\hline & - & 3 & 15 \\
\hline \multirow{2}{*}{$0.125 \mathrm{~g} / \mathrm{ml}$} & + & 19 & 95 \\
\hline & - & 1 & 5 \\
\hline
\end{tabular}


When we evaluate at the taste functions, we can see that the four main taste sensations evaluated as bitter, sweet, sour and salty vary according to three different concentrations (low, medium, high), the sense of sweet and sour taste is $100 \%$ at high concentration, It has been seen that it has gradually decreased. While all low-concentration cases can not perceive taste sensation $(n=20)$ for medium and high concentrations of bitter and salty taste, the level of perception is gradually increasing but not reaching $100 \%$.

\section{DISCUSSION}

Postoperative nasal physiological changes is a well known feature in total laryngectomy received patients. Nasal mucosal atrophy generally occurs in such patients. Upper respiratuary tract is disconnected with air after tracheostomy and this leads to some nasal mucosal changes. In some studies, hyposmiaanosmia appeared after total laryngectomy and it is thought that this is related to neural disturbance between nose and larynx $(11,12)$. There are some recent studies which concluded total laryngectomy causes hyposmic and anosmic patients as well $(10,16-18)$ Our study revealed the similar result as half of the patients $(n=10)$ were anosmic and the other half $(n=10)$ were hyposmic patients. The mean thresold value in our study is $3,95 \pm 2,63$ and compatible with literature. In our study, like other studies we used CCCRC test which includes a butanol threshold test as well as an odor identification test using common odors $(13,14)$. This is a cost effective, practical and simple test (15).

In an other similiar study which investigated life quality on total larengectomy receiving patients, taste sense disfunction is reported as one of the major factors affecting life quality (16). In our study, sensation of sucrose, $\mathrm{NaCl}$ and quinine hydrochloride in all the concentrations did not make any difference between anosmic and severe hyposmic patients. All the severe hyposmic patients sensed $0,01 \mathrm{~g} / \mathrm{ml}$ citric acid concentration, but only $60 \%$ of anosmic patients sensed it. It seems there is a trend to anosmic patients have poorer sensation of sour taste, but this result was not statistically different. In our opinion, the possible reason is either small sample size

Adress for correspondence: Ankara Onkoloji Hastanesi 5. Kat Kbb Kliniği Ankara - Türkiye e-mail: ttunccan@gmail.com

Available at www.actaoncologicaturcica.com

Copyright $\odot$ Ankara Onkoloji Hastanesi or the concentration of the solution. If more diluted concentration of citric acid were used, we could be able to catch the statistically difference.

As taste sensation is a subjective factor, it's evaluation is not easy. If a control group was designed, more accurate results could be achieved. In our study, the primary target was to distinguish the minimum concentration of the solution from water. Foulkes reported that as taste and smell functions may differ according to etiology, age and cultural factors, objective criterias are needed in evaluation of these functions (19). For this reason, best sensation among 4 main tastes may be different among patients.

Lennie et al. showed the decrease in taste and smell functions after laryngectomy that caused difficulty in alimentation (10). Although statistically significance was not established, our study revealed the change in taste function on total laryngectomy received patients. Small sample size and absence of control group are the weakness of the present study, nevertheless there are few studies investigating taste function after total laryngectomy in literature.

\section{CONCLUSION}

Total laryngectomy can causes decrease in olfactory functions and taste functions tend to decrease as well. However, prospective controlled studies with large sample size are needed to make the final decision.

\section{REFERENCES}

1. Maurizi M, Paludetti G, Almadori G, Ottaviani F, Todisco T. Mucociliary clearance and mucosal surface characteristics before and after total laryngectomy. Acta Otolaryngol 1986;102:136-45.

2. Gillion VM. The nose after larygectomy. J R Soc Med 1985;78:435-9.

3. Castellanos, P.F., Spector, J.G., Kaiser, T.N. Tumors of the larynx and laryngopharynx. in: J.J. Ballenger, J.B. Snow Jr (Eds.) Otorhinolaryngology Head and Neck Surgery. ed 15. Williams \& Wilkins, Baltimore, MD 2000. p-585-652.

4. Cummings Otolaryngology - Head and Neck Surgery, 5th Edition, Volume 2 Chapter 3; 865-897.

5. Scherer PW, Hahn II, Mozell MM.The biophysics of nasal airflow. Otolaryngol Clin North Am. 1989 Apr;22(2):265-78.

6. Doty RL, Frye R: Influence of nasal obstruction on smell function, Otolaryngol Clin North Am 22, 1989: 397. 
7. Bailey BJ.\&Jonas T.Johnson Baş \& Boyun Cerrahisi-Otolarengoloji, 2011,p-568-570

8. Metreau A, Louvel G, Godey B, Clech GL, Jegoux F. Long term functional and quality of life evaluation after treatment of advanced pharyngolaryngeal carcinoma. Head Neck. 2013 Sep 30. doi: 10.1002/hed.23503

9. Risberg-Berlin B, Ylitalo R, Finizia C. Screening and rehabilitation of olfaction after total laryngectomy in Swedish patients: results from an intervention study using the Nasal AirflowInducing Maneuver.. Arch Otolaryngol Head Neck Surg. 2006 Mar;132(3):301-6.

10. Lennie TA, Christman SK, Jadack RA. Educational needs and altered eating habits following a total laryngectomy. College of Nursing at Ohio State University, Columbus, USA.Oncol Nurs Forum. 2001 May;28(4):667-74.

11. Hanna E, Sherman A, Cash D, Adams D, Vural E, Fan CY, Suen JY. Quality of life for patients following total laryngectomy vs chemoradiation for laryngeal preservation. Arch Otolaryngol Head Neck Surg. 2004 Jul;130(7):875-9.

12. Fisher EW, Liu M, Lund VJ. The nasal cycle after deprivation of airflow: A study of laryngectomy patients using acoustic rhinometry. Acta Otolaryngol 1994;114(4):443-6.
13. Hoye RC, Ketcham AS, Henkin RI. Hypoosmia following paranasal sinus exenteration or laryngectomy Am J Surg. 1970;120:485-91.

14. Henkin RI, Larson AL. On mechanisms of hypoosmia following laryngectomy in man. Laryngoscope 1972;82:836-43.

15. Leon EA, Catalanotto FA, Werning JW. Retronasal and Orthonasal Olfactory Ability After Laryngectomy,Arch otolaryngol head neck surgery 133,Jan 2007.

16. Cain WS,Gent JF, Goodspeed RB, Leonard G. Evaluation of olfactory dysfunction in the Connecticut Chemosensory Clinical Research Center.Laryngoscope.1988;98:83-88.

17. Cain WS,Testing olfaction in a clinical setting.Ear Nose Throat J.1989;68:316,322-328

18. Veyseller B, Ozucer B,Karaaltin AB, Yildirim Y, Degirmenci N, Aksoy F, Ozturan O. Connecticut (CCCRC) olfactory test: Normative data set in 426 healthy Turkish volunteers. Department of Otorhinolaryngology, Bezmiâlem Vakıf University, Fatih, İstanbul, Turkey. Otorhinolaryngology Clinic, Istanbul Training and Research Hospital, Istanbul, Turkey.

19. Design issues in chemosensory trials.Foulkes MA.Arch Otolaryngol Head Neck Surg. 1990 Jan;116(1):65-8 